\title{
Assessing Primary School Teachers's Knowledge of Specific Learning Disabilities in the Kingdom of Saudi Arabia
}

\author{
Nsreen A. Alahmadi ${ }^{1}$ \& Mogeda El Sayed El Keshky ${ }^{2,3}$ \\ ${ }^{1}$ English Language Institute, King Abdulaziz University, Jeddah, Saudi Arabia \\ ${ }^{2}$ Department of Psychology, Faculty of Arts and Humanities, King Abdulaziz University, Jeddah, Saudi Arabia \\ ${ }^{3}$ Department of Psychology, Faculty of Arts, Assiut University, Egypt \\ Correspondence: Mogeda El Sayed El Keshky, King Abdulaziz University, Faculty of Arts and Humanities, \\ Department of Psychology, P.O. Box 42803, Jeddah 21551, Saudi Arabia. E-mail: drmogeda@gmail.com
}

Received: October 15, 2018 Accepted: November 13, 2018 Online Published: November 19, 2018

doi:10.5539/jedp.v9n1p9 URL: http://doi.org/10.5539/jedp.v9n1p9

\begin{abstract}
Purpose: Children with Learning disabilities require exceptional attention from family, their social circle and teachers. Because moral support and learning are initiated in the school environment by teachers (Padmavathi \& Lalitha, 2009), the aim of this study is to evaluate primary school teachers' knowledge about special learning disabilities in the Kingdom of Saudi Arabia.

Material \& Method: A sample of 902 primary private and puplic school teachers from 78 schools across different regions of Saudi Arabia was selected using a convenience sampling technique. Teachers' knowledge about learning disabilities was surveyed electronically using a structured knowledge 40-item questionnaire on learning disabilities. A descriptive and quantitative approach was used to assess their knowledge. SPSS v21 was used to analyze the data.

Results: The study found that a majority of primary school teachers have average knowledge about specific learning disabilities. Consequently, teachers' range of knowledge has statistically significant impact on their level of knowledge. The study correspondingly shows a significant relationship between levels of knowledge and socio-demographic variables, but no statistically significant difference in the knowledge level of male and female teachers regarding learning disabilities.

Conclusion: Teachers do not have adequate knowledge regarding learning disabilities, and do not know what should be done when facing such issue. Teachers' knowledge about learning disabilities is insuficient, because their academic training did not include any courses about it. As a consequence, education lawmakers should arrange appropriate teacher training or structured learning programs regarding learning disability concepts, assessment, diagnosis and identification for such teachers.
\end{abstract}

Keywords: learning disabilities, knowledge, school teachers, primary school, Saudi Arabia

\section{Introduction}

The absence of supportive legislation for people with disabilities in any society displays its lack of recognition of disability. Such absence of supportive legislation raises concern about the protection and opportunities for individuals with disabilities, however legislation alone is insufficient for changing the general public's acceptance of people with disabilities. The public attitude to their acceptance is a vital factor in the struggle for equality, even if individuals with disablies have been granted legal access to educational opportunities and public places. Consequently, there is a need to enlighten the attitudes of individuals towards those with disablies. This can be best achieved by providing awareness about specific learning disabilities from primary schooling onwards (Ghimire, 2017).

Teachers play a very important role in the early diagnosis of any student's learning issues, especaily mental health problems. Early recognition is important and can make a big difference to the child's future, so teachers play a vital role in the early identification and appropriate guidance for families. Karande, Bhosrekar, Kulkarni and Thakker (2008) found that primary teacher trainees should have adequate knowledge about specific learning disabilities for raising teacher competence. 
A learning disability is a disorder referring to difficulties in listening, speaking, reading, writing and mathematics. 10 of every 100 school children are said to suffer from learning disabilities in the world (Sakhuja, 2004). According to the Ministry of Health (2012), there are around 720000 children with disabilities in the Kingdom of Saudi Arabia (KSA) from a Saudi population of 29 million, which means that 400 to 500 children are born with disabilities from the 400000 to 500000 births annually. The common learning disabilities are dyslexia (a problem with reading); dysgraphia (a problem with writing, spelling, handwriting); dyscalculia (a problem with mathematics); dyspraxia (poor balance and eye-hand coordination) (Himalayan Times, 2009). A child with learning disabilities actually has several related difficulties which last over time and whose signs differ from one child to another. Moothedath and Vranda (2015) found that children with learning disabilities have difficulty in trying their best, have a low attention span and cannot motivate themselves on their own. It is not related to intelligence, but it is caused by a process that affects receiving, processing and communicating information.

Schools are hostile towards learning disabilities in general. The teacher's lack of competencey in dealing with the charcteristic and behaviors of learning disabilities in children as well as their identification affects the child's self-esteem and discourages them from study (Dalwai, Ahmad \& Al-Nakib, 2010). This challenges teachers to find and provide the suitable instruction on their own to those children, who consequently find it difficult to adjust in school.

Learning disabilities in school-aged children are one of the common problems that need special attention from family, neighbors, social circles and teachers. The source of best support and good resources should be found in the school environment by teachers (Avramidis \& Norwich, 2002).

With an area of 865000 square miles the KSA covers $80 \%$ of the Arabian Peninsula (Abed \& Alrawajfh, 2017). Islam is the official religion and covers all aspects of people's lives. It emphasizes the importance of education. The education system is categorized into three levels: Kindergarten, Primary and Secondary education, in addition to Territory level universities. Saudi education has recently paid more attention to special educational needs and, particularly, to the area of learning disabilities. In 2006, the Saudi Learning Disability Program (SLDP) was established in 728 boy's and 498 girl's primary schools, respectively, serving 15038 students in total (Alnaim, 2015). The Saudi education system has also started focusing on providing quality programs for teacher's development for the acquisition of skills and knowledge about learning disabilities (Al-Zoubi \& Rahman, 2016).

People with learning disabilities have difficulty processing sensory information because they see, hear and understand things differently. According to Priestley (2003) a learning disability, sometimes called a learning disorder or learning difficulty, occurs when a person has a difficulty in learning in a typical manner. A study conducted by Shenoy and Kapoor (1996) to assess the factors affecting learning in children revealed that teacher negligence, parental bad behavior and poor instruction are the factors responsible for learning problems. Children with learning difficulties are an at-risk population: they have trouble in expressing their feelings and calming themselves. They are likely to develop low self-esteem, have fewer friends, and are one and a half times more likely to drop out of school. They need to be identified at an earlier stage, so proper training and guidance can be provided to them (Vandenberg \& Emery, 2009).

Earlier researchers on the subject found that primary school teachers have low levels of knowledge, awareness and understanding about specific learning abilities (Adebowale \& Moye, 2013; Lingeswaran, 2013; Shari \& Vranda, 2016; Ghimire, 2017). Moothedath and Vranda (2015) found that only 5\% of teachers had adequate knowledge about learning disabilities. There were statistically significant differences in overall knowledge, causes and classification, clinical manifestation, investigations across the gender variable. In developed and under-developed countries, teachers and parents are usually not aware of learning problems found in children. Karande, Bhosrekar, Kulkarni and Thakker (2008) found that primary school teacher trainees do not have adequate knowledge about specific learning disabilities in India, but they asserted that since teachers are the ones who have the ability to identify difficulties among students, their support is greatly affected by their lack of knowledge and understanding regarding specific learning disabilities.

A report published by the Ministry of Education (2012) stated that professional development and education for teachers is promising as it enables them to understand whether their students have learning disabilities or not. According to Kamala and Ramganesh (2013), primary teachers had an average knowledge about learning disabilities and that there was a significant difference according to their gender about their level of knowledge. Gandhimathi and Eljo (2010) argued that the nature of school, teacher age and teaching experience have no statistically significant relationship to awareness regarding learning disabilities. Dharmaraj (2000) concluded that teachers with a higher education have more awareness about learning disabilities.

These earlier works all point to the importance of conducting an up-to-date study about the knowledge of specific 
learning disabilities among the primary school teachers in the KSA. If the special needs of children with learning disabilities are not attended to, it will result in scholastic backwardness and related psycho-social problems. Thus, early identification and intervention are very important. The ultimate focus of this study is to help teachers by developing a manual that could contribute to identifying children with learning disabilities.

\subsection{Significance of the Study}

Most teachers today are unaware of learning disabilities among the students and the legal ramifications of negligence.

By affecting about 10-15 percent of school-aged children, learning disability constitutes one of the major health problems affecting educational processes. Reading and learning are the two things that determine the success of a child's school career. First the child learns to read, and then the child reads to learn. Reading is therefore of paramount importance in the educational process (McDermott, 2001). Dr. Saja Jamjoom, a Program Manager for the Learning Disabilities Program at the Prince Salman Center for Disability Research based in Riyadh, suggested in a conference in Riyadh on the learning disabilities that the Saudi education system has approximately 215000 students struggling with learning disabilities (Arab News, n.d.).

Because education is a fundamental right of every citizen, it is also increasingly evident that a healthy, inclusive and high-quality system of school education is essential for the development of children. Early recognition and adequate remediation are important and can make a big difference to a child's future. A child's personality is considerably influenced by the character and conduct of their surrounding peers. As school children spend more time with their school teachers, the teachers are in an ideal position to help families in early identification of problems and to provide appropriate guidance. Dr. Jamjoom (Arab News, n.d.). maintained that teacher trainees should have adequate knowledge, and as a result, this study focusses on what knowledge there is of special learning disabilities among teacher trainees.

Ultimately, planned teaching programs will have a positive influence on school teachers so they know more about the behaviors that indicate learning disabilities among children. Dedication, devotion and discipline along with enormous patience and love for the children alone will help a teacher to encourage students with such disabilities to overcome them and learn slowly but gradually.

\subsection{Research Questions}

The following research questions are addressed by this study:

- What is the primary school teacher level of knowledge about special learning disabilities in Saudi Arabia?

- What is the relationship between different dimensions of knowledge and a primary school teacher's overall level of knowledge about learning disabilities?

- Does the gender of primary teachers have significance for their level of knowledge about special learning disabilities?

- Do teachers teaching in different types of schools have significant differences in their level of knowledge about special learning disabilities?

- Do socio-demographic factors influence positively the level of knowledge about special learning disabilities?

\subsection{Research Objectives}

The research objectives of this paper are to:

- Evaluate the primary school teacher level of knowledge about special learning disabilities in Saudi Arabia.

- Assess the relationship between different dimensions of knowledge and primary school teacher overall level of knowledge about learning disabilities.

- Determine whether gender of primary school teachers has significance for their level of knowledge about special learning disabilities.

- Determine whether teachers from different types of schools have significant differences in their level of knowledge about special learning disabilities.

- Explore the impact of different socio-demographic factors on the level of understanding about learning disabilities.

\section{Literature Review}

Earlier researchers have completed numbers of studies to explore primary school teachers' level of knowledge and 
understanding about specific learning disabilities and their frequency among school children across the globe (Moothedath \& Vranda, 2015; Akpan, Ojinnaka \& Ekanem, 2010; Padmavathi \& Lalitha, 2009; Myers \& Johnson, 2007; Chappel, Goodley \& Lawthom, 2001). A recent study by the National Institute of Health (2017) shows that children under 15 years of age have dyslexia, and nearly 1 in 100 school-aged children have been found to have dyslexia with poor attention and concentration. The World Health Organization (WHO, 2003) has declared that learning disabilities affect 1 in 10 children. Nearly 4 million school children have a learning disability. Prevalence of learning disabilities is conservatively estimated at 215000 in the general school-aged population in Saudi Arabia (Arab News, n.d.).

Moothedath and Vranda (2015) explored the knowledge of special learning disabilities among teachers at the primary level in Bangalore. The study took a sample of 200 teachers and found that there was a statistically significant relationship in overall level of knowledge and teacher gender, education, years of experience, type of school and class being taught. A similar study was conducted by Padhy, Goel, Das, Sarkar, Sharma and Panigrahi (2016) to investigate teacher perceptions about learning disabilities in the public schools of slum areas of Chandigarh, India. A purposive sampling technique was adopted to obtain a sample of 80 teachers from 103 schools there. A cross-sectional questionnaire was used to measure the teachers' perceptions regarding learning disabilities. It was found that $56.3 \%$ of them were aware of learning disabilities and approximately $68 \%$ of respondents believed that they did encounter such children in school.

Shanker (2015) also investigated the impact of structured teaching programs on the level of knowledge of 60 teachers. The results revealed that teachers had very limited knowledge about learning disabilities, but that structured teaching programs contributed positively to enhance their knowledge. A study conducted by Shari and Vranda (2015) found that only 5\% of teachers had adequate knowledge about learning disabilities. There were statistically significant differences in overall knowledge, causes and classification, clinical manifestation and investigations across the gender variable. In both developed and under-developed countries, teachers and parents were usually not aware of learning problems found in children.

Shukla and Agarwal (2014) found that $67 \%$ of teachers had no understanding about learning disabilities among primary school children, $20 \%$ of them had a very low level of understanding and only $12 \%$ knew about specific learning disabilities in the Haridwar region. Pawar and Mohith (2014) concluded that a self-instructional module brought significant improvement to the knowledge of primary school teachers regarding this issue. Williams et al. (2013) investigated a sample of 38 school teachers to explore a teacher training program's effectiveness for their understanding and knowledge about specific learning disabilities. By using convenient sampling technique and a quasi-experimental study, they found such teacher training programs played a significant role in increasing the level of knowledge about learning disabilities among primary school teachers in Bhainyawala, Dehradun.

Bhanwara, Kelkar and Mandalia (2012) described how planned teaching is effective in increasing the knowledge regarding learning disabilities. The study was conducted in selected schools of the city of Pune, using samples of 60 for both male and female teachers, and a non-convenient purposive sampling technique. Teachers acquired adequate knowledge according to the results. According to the Huffington Post (Rowan, 2014) video games are helpful in improving the writing and reading skills of learning-disabled children since they train the brain parts responsible for motion perception and attention. However, video games should only be allowed to children in the presence of their parents.

Natekar (2012) conducted a study to assess the knowledge of primary school teachers about learning disabilities and their prevention among children in Bangalore. A self-administered structured questionnaire was prepared and administered to 50 primary school teachers between the First to Seventh standard based on a purposive sampling technique. The outcome was that teachers did acquire adequate knowledge regarding learning disabilities. According to Karande, Sholapurwala and Kulkarni (2011), 15\% of school children were affected by learning disabilities in India. Although the government has carried out various awareness campaigns over the last decade, much is needed to be done to achieve an ideal scenario. For this, teachers will play a vital role, so proper training is required for screening for learning disability in primary school. School management should offer structured teaching programs and employ special instructors to ensure that children receive regular remedial education.

Karande and Gogtay (2010) observed that teachers in educational institutions might draw on many subjects, including reading, writing, and mathematics during the education of their students. Most teachers acted in a friendly manner towards students, as a guide, father, mother, friend or companion, and therefore had the ability to identify symptoms of learning disability in children in the early stages. Gandhimathi and Eljo (2010) argued that the nature of a school, teacher's age and teaching experience have no statistically significant relationship with awareness of learning disabilities. Wheldall and Limbrick (2010) in their study assessing the prevalence of reading 
problems among boys and girls in Australia found that reading problems were more common in boys than girls. A cross sectional study was conducted by Akpan, Ojinnaka and Ekanem (2010) among 572 students from six randomly selected private and public primary schools in Uyo, Nigeria and found a high incidence of learning disabilities among the children.

Padmavathi and Lalitha (2009) assessed a structured teaching program's effectiveness on primary school teacher levels of knowledge about specific learning disabilities in Karnataka, India. They found significant differences between the pre-test and post-test results for a sample of 30 trainees and concluded that structured programs are effective in positively modeling the knowledge required by primary teachers about learning disabilities. According to Gupta (2008) learning disabilities were commonly observed in the 3-5 years age group, most commonly among $10 \%$ of girls and $15 \%$ of boys. Dyslexia is a lifelong condition, although early identification and treatment allows many people to learn to read and write (Myers \& Johnson, 2007). They concluded therefore, that systematic teaching programs, structured workshops and training for primary teachers and therapists should be made part of teacher training modules in the education system.

Al-Khatib (2007) investigated the knowledge of 405 regular teachers about learning disabilities with the help of t-tests and ANOVA in Jordan. They found females to be significantly more knowledgeable than males. It showed that $76 \%$ of the teachers improved their ability in identifying children in need of mental health referral, and $88 \%$ reported that the education program reduced the likelihood of suspensions and expulsion. Das, Hayward, Samantaray and Panda (2006) conducted a cross-sectional observation study of 454 students primary school children in Kathmandu Valley. The study's aim was to find out morbidity in habit and learning disabilities in the 6-10 years age group and it revealed a statistical gender-wise difference in learning disabilities. The morbidity was due to multiple factors from the psycho-social environment. There was also a greater severity of co-morbidity.

A study was conducted by Singal (2005) regarding remedial programs for children with learning disabilities to measure the intellectual development of children with learning disabilities, to provide a psycho-education program and to conduct a teaching program for teachers in Tamil Nadu. This study used different methods like general intelligence and attitude tests, as well as general achievement and personality tests. It suggested an orientation program about learning disability be arranged for the teachers. A quasi-experimental study using a sample of 32 teacher trainees was conducted by the National Institute of Mental Health and Neuro Sciences Bangalore (2005), to assess the effectiveness of a structured teaching program for teacher trainee levels of knowledge about learning disabilities. The study concluded that teacher trainee programs are effective in improving knowledge of teachers. According to Kamala and Ramganesh (2013), primary teachers had an average knowledge about learning disabilities and there were significant differences based on their gender and level of knowledge. Dharmaraj (2000) concluded that teachers with higher education have more awareness about learning disabilities.

\subsection{Research Hypotheses}

There are five research hypotheses:

- That there is a low level of knowledge among primary school teachers about learning disabilities in Saudi Arabia.

- That there is significant relation between different dimensions of knowledge and the overall level of knowledge about learning disabilities.

- That the socio-demographics of primary school teachers has significant impact on their level of knowledge about special learning disabilities.

- That the gender of primary school teachers has significance for the level of knowledge about special learning disabilities.

- That the school type is significant for the level of knowledge of primary school teachers about special learning disabilities.

\section{Research Methodology}

The study was conducted to assess the knowledge of special learning disabilities among the primary school teachers in KSA. A descriptive and quantitative cross-sectional approach was used. A sample of 902 private and puplic school teachers was gathered with the help of a structured knowledge questionnaire about learning disabilities. A convenient sampling technique was used. The research was conducted in 78 schools across different regions of Saudi Arabia. The questionnaire was adapted and developed from existing work by Padmavathi and Lalitha (2009) and Shari and Vranda (2015).

Because the pilot study suggested that an Arabic version of the questionnaire should be developed for the survey as 
primary teachers might face problems in an English-developed instrument, which might lead to ambiguous results, an Arabic (local language) version of the questionnaire was used.

Table 1. Dimensions in the Knowledge Questionnaire

\begin{tabular}{lcc}
\hline Dimensions & Items & Percentage \\
\hline Concept and Definition & 4 & 10.0 \\
Incidence and Prevalence & 3 & 7.5 \\
Causes and Classification & 3 & 7.5 \\
Clinical Manifestations & 13 & 32.5 \\
Approaches to Assessment & 5 & 12.5 \\
Interventions & 10 & 25.0 \\
Outcome & 2 & 5.0 \\
\hline Total & 40 & 100 \\
\hline
\end{tabular}

The questionnaire was divided into two sections. The first section provides the socio-demographic variables for the study, while the second section comprises 40 items of knowledge questions about learning disabilities divided into the seven dimensions seen in Table 1. The level of knowledge was categorized into good, average and poor.

However, to explore the association between different dimensions of knowledge for primary school teachers' overall level of knowledge, a questionnaire was also developed on a 3-point Likert scale. Since reliability and validity of an instrument are independent of the number of scale points used for Likert-type items (Bending, 1954; Komorita, 1963; Komorita \& Graham, 1965), the research used only a reduced number of items in the 3-point Likert scale to address this association between the dimensions in Saudi Arabia. To check the reliability of the questionnaire, a pilot survey from 30 primary teachers was first conducted to explore the research feasibility and suitability of the research tools. It reflected a Cronbach alpha value of 0.704 which is good, as indicated by Kline (1986). A different descriptive, frequency and percentage distribution was used to determine the level of knowledge. A Chi-Square Test and a One Sample independent test were used to associate the knowledge of primary school teachers with the demographic variables. SPSS v21 was used to analyze the collected data. Adhering to ethical considerations and confidentiality of the research, the data was collected by an electronic questionnaire with the consent of respected school teachers.

\section{Results}

Table 2. Frequency and Percentage Distribution of Socio-Demographic Variables for Primary School Teachers

\begin{tabular}{llll}
\hline $\begin{array}{l}\text { Socio-Demographic } \\
\text { Variable }\end{array}$ & Categories & Frequency & Percentage \\
\hline \multirow{2}{*}{ Gender } & Male & 165 & 18.3 \\
\cline { 2 - 4 } & Female & 737 & 81.7 \\
\hline \multirow{2}{*}{ Age } & $20-35$ & 222 & 24.6 \\
\cline { 2 - 4 } & $36-50$ & 623 & 69.1 \\
\hline & $51-65$ & 57 & 6.3 \\
\cline { 2 - 4 } Experience & $0-5$ & 89 & 9.9 \\
\hline & $6-10$ & 296 & 32.8 \\
\hline & $11-15$ & 100 & 11.1 \\
\hline
\end{tabular}




\begin{tabular}{|c|c|c|c|}
\hline \multirow{4}{*}{ Marital Status } & Single & 69 & 7.6 \\
\hline & Married & 775 & 85.9 \\
\hline & Divorced & 44 & 4.9 \\
\hline & Widow & 14 & 1.6 \\
\hline \multirow{4}{*}{ Education } & Bachelors & 644 & 71.4 \\
\hline & Masters & 35 & 3.9 \\
\hline & $\mathrm{PhD}$ & 5 & 0.6 \\
\hline & Diploma/Certificate & 218 & 24.2 \\
\hline \multirow{2}{*}{ Type of School } & Government & 854 & 94.7 \\
\hline & Private & 48 & 5.3 \\
\hline \multirow{3}{*}{ Class Taught } & Lower Primary & 327 & 36.3 \\
\hline & Upper Primary & 361 & 40.0 \\
\hline & All Classes & 214 & 23.7 \\
\hline \multirow{2}{*}{ Working with Counselors } & Yes & 487 & 54.0 \\
\hline & No & 415 & 46.0 \\
\hline \multirow{2}{*}{$\begin{array}{l}\text { Identification of Child with Learning } \\
\text { Disabilities }\end{array}$} & Yes & 535 & 59.3 \\
\hline & No & 367 & 40.7 \\
\hline \multirow{2}{*}{ Training and Development } & Yes & 127 & 14.1 \\
\hline & No & 775 & 85.9 \\
\hline
\end{tabular}

As it can be seen in Table 2, a total of 737 (81.7\%) females participated in the survey and $165(18.3 \%)$ males. A majority of respondents, i.e. $623(69.1 \%)$, were in the 36-50 years age group followed by $222(24.6 \%)$ respondents in 20-35 years age group. A total of $296(32.8 \%)$ respondents had 6-10 years of experience in teaching primary children; $258(28.6 \%)$ had above 21 years of experience and $159(17.6 \%)$ had 16-20 years of experience. 775 (85.9\%) respondents were married; 644 (71.4\%) respondents had a bachelor's degree. Out of 902 surveyed participants, 854 (94.7\%) belonged to government schools while only 48 (5.3\%) were from public schools. 361 (40.0\%) respondents taught at the upper primary level, 327 (36.35) taught lower primary and the remaining 214 (23.7\%) respondents taught all class levels. A majority of respondents, $535(65.3 \%)$ had identified a child with learning disabilities before. $85.9 \%$ participants claimed that they weren't provided with appropriate training and workshop to identify, diagnose or screen the learning disabilities in children.

Table 3. Descriptive Statistics of Dimensions on Knowledge Questionnaire

\begin{tabular}{lcccc}
\hline Dimensions & Max. Items & Mean & Standard Deviation & N \\
\hline Concept and Definition & 4 & 2.08 & 1.00 & 902 \\
Incidence and Prevalence & 3 & 0.93 & 0.79 & 902 \\
Causes and Classification & 3 & 1.11 & 0.82 & 902 \\
Clinical Manifestations & 13 & 5.83 & 1.89 & 902 \\
Approaches to Assessment & 5 & 3.83 & 1.12 & 902 \\
Interventions & 10 & 5.43 & 1.60 & 902 \\
Outcome & 2 & 1.23 & 0.67 & 902 \\
\hline Total (Overall) & 40 & 20.45 & 3.90 & 902 \\
\hline
\end{tabular}

Table 3 shows the outcomes of all the items and the mean knowledge score of the different dimensions and standard deviation, both overall and for different dimensions of the knowledge questionnaire. For an overall 
knowledge, with the maximum score of 40 , the mean score was 20.45 having a standard deviation value of 3.9.

The majority of primary school teachers in the KSA, $582(64.52 \%)$ had only average knowledge about specific learning disabilities, and 320 (35.48\%) of them had poor knowledge. None had good knowledge of learning disabilities.

Table 4. Association of Primary School Teacher Level of Knowledge with their Socio-Demographic Variables

\begin{tabular}{|c|c|c|c|c|c|c|c|c|}
\hline \multirow{2}{*}{ Demo-graphic Variable } & \multirow{2}{*}{ Categories } & \multicolumn{2}{|c|}{ Level of Knowledge } & \multirow{2}{*}{$\mathrm{N}$} & \multirow{2}{*}{$\mathrm{df}$} & \multicolumn{2}{|c|}{ Test Statistics } & \multirow[t]{2}{*}{ Inference } \\
\hline & & Poor & Average & & & Chi Sq. & $\mathrm{P}$ value & \\
\hline \multirow{2}{*}{ Gender } & Male & 63 & 102 & 165 & \multirow{2}{*}{1} & \multirow{2}{*}{48.52} & \multirow{2}{*}{0.001} & \multirow{2}{*}{ Significant } \\
\hline & Female & 342 & 395 & 737 & & & & \\
\hline \multirow{3}{*}{ Age } & $20-35$ & 102 & 120 & 222 & \multirow{3}{*}{2} & \multirow{3}{*}{51.24} & \multirow{3}{*}{0.211} & \multirow{3}{*}{$\begin{array}{l}\text { Not } \\
\text { Significant }\end{array}$} \\
\hline & $36-50$ & 273 & 350 & 623 & & & & \\
\hline & $51-65$ & 30 & 27 & 57 & & & & \\
\hline \multirow{5}{*}{ Experience } & $0-5$ & 39 & 50 & 89 & \multirow{5}{*}{4} & \multirow{5}{*}{91.32} & \multirow{5}{*}{0.383} & \multirow{5}{*}{$\begin{array}{l}\text { Not } \\
\text { Significan }\end{array}$} \\
\hline & $6-10$ & 146 & 150 & 296 & & & & \\
\hline & $11-15$ & 38 & 62 & 100 & & & & \\
\hline & $16-20$ & 61 & 98 & 159 & & & & \\
\hline & 21 or + & 121 & 137 & 258 & & & & \\
\hline \multirow{4}{*}{ Marital Status } & Single & 34 & 35 & 69 & \multirow{4}{*}{3} & \multirow{4}{*}{90.66} & \multirow{4}{*}{0.024} & \multirow{4}{*}{ Significant } \\
\hline & Married & 344 & 431 & 775 & & & & \\
\hline & Divorced & 21 & 23 & 44 & & & & \\
\hline & Widow & 6 & 8 & 14 & & & & \\
\hline \multirow{4}{*}{ Education } & Bachelors & 298 & 346 & 644 & \multirow{4}{*}{3} & \multirow{4}{*}{95.27} & \multirow{4}{*}{0.011} & \\
\hline & Masters & 4 & 31 & 35 & & & & \\
\hline & $\mathrm{PhD}$ & 1 & 4 & 5 & & & & Signiticant \\
\hline & Diploma/Certificate & 102 & 116 & 218 & & & & \\
\hline & Govt & 381 & 473 & 854 & & & & \\
\hline Type of School & Private & 24 & 24 & 48 & 1 & 99.49 & 0.000 & Significant \\
\hline & Lower Primary & 145 & 182 & 327 & & & & \\
\hline Class Taught & Upper Primary & 172 & 189 & 361 & 2 & 66.07 & 0.017 & Significant \\
\hline & All Classes & 88 & 126 & 214 & & & & \\
\hline Working & Yes & 209 & 278 & 487 & 1 & 3404 & 0030 & Sionificant \\
\hline Counselors & No & 196 & 219 & 415 & 1 & 34.94 & 0.039 & Signiticant \\
\hline $\begin{array}{l}\text { Child Identific-ation } \\
\text { with } \\
\text { LearningDisabilities }\end{array}$ & Yes & 248 & 287 & 535 & 1 & 48.88 & 0.001 & Significant \\
\hline
\end{tabular}


Table 4 shows the outcome of the Chi-Square analysis which brings out the association between the knowledge of primary school teachers and their socio-demographic variables. The results indicate that gender, marital status, education, school type, class involved in teaching, working with counselors and identification of child with learning disabilities are found to be statistically significant as their p-values were below the level of significance of 0.05 . The other socio-demographic factors such as age ( $p$-value $>0.211)$ and years of teaching experience $(p$-value $>$ 0.383 ) were not significant for their level of knowledge.

Additionally, this study analyzes the differences between the level of knowledge of the male and female participants and the type of schools.

Table 5. Independent Sample T-test (Knowledge vs. Demographic Variables)

\begin{tabular}{|c|c|c|c|c|c|c|c|c|c|c|}
\hline & & \multicolumn{3}{|c|}{ Group Statistics } & \multicolumn{3}{|c|}{$\begin{array}{l}\text { Levene's Test for Equality of } \\
\text { Variances }\end{array}$} & \multicolumn{3}{|c|}{$\begin{array}{l}\text { T-test for Equality of } \\
\text { Means }\end{array}$} \\
\hline & & $\mathrm{N}$ & Mean & $\begin{array}{l}\text { St. } \\
\text { Dev }\end{array}$ & $\begin{array}{l}\text { Equal } \\
\text { vaiances }\end{array}$ & $\mathrm{F}$ & Sig & $\mathrm{t}$ & df & $\begin{array}{l}\text { Sig. } \\
\text { (2-tail) }\end{array}$ \\
\hline \multirow{2}{*}{$\begin{array}{l}\text { Level of Knowledge } \\
\text { Gender }\end{array}$} & Male & 165 & 20.91 & 3.9 & assumed & 0.25 & 0.014 & 1.65 & 900 & 0.098 \\
\hline & Female & 737 & 20.35 & 3.8 & not assumed & & & 1.62 & 237 & 0.106 \\
\hline \multirow{2}{*}{$\begin{array}{l}\text { Level of Knowledge } \\
\text { Type of School }\end{array}$} & Govt. & 854 & 20.56 & 3.7 & assumed & 20.5 & 0.000 & 3.54 & 900 & 0.000 \\
\hline & Private & 48 & 18.52 & 5.3 & not assumed & & & 2.61 & 49.6 & 0.012 \\
\hline \multirow{2}{*}{$\begin{array}{l}\text { Level of Knowledge } \\
\text { Identification }\end{array}$} & Yes & 535 & 20.36 & 4.1 & assumed & 2.7 & 0.099 & -0.87 & 900 & 0.384 \\
\hline & No & 367 & 20.59 & 3.6 & not assumed & & & -0.89 & 844 & 0.373 \\
\hline
\end{tabular}

Table 5 shows that the male participant mean value (male $=20.91$ ) is slightly greater than that of the female participant at 20.35, which means that males have a greater level of knowledge about learning disabilities in Saudi Arabia. Levene's Test p-value is greater than the level of significance indicating that the variance across the groups is statistically significant. Similarly, the government teacher mean value (male $=20.56$ ) is greater than that of the private teacher mean value at 18.52, which means that government primary school teachers have a greater and statistically significant level of knowledge about learning disabilities in Saudi Arabia. Many respondents indicated that they had not identified a child with learning disabilities before, but that result was not statistically significant.

Table 6. Correlations

\begin{tabular}{|c|c|c|c|c|c|c|}
\hline & $\begin{array}{l}\text { Concepts and } \\
\text { Definition }\end{array}$ & $\begin{array}{l}\text { Incidence and } \\
\text { Prevalence }\end{array}$ & $\begin{array}{l}\text { Causes and } \\
\text { Classific-ation }\end{array}$ & $\begin{array}{l}\text { Clinical } \\
\text { Manifestation }\end{array}$ & $\begin{array}{l}\text { Assessment } \\
\text { Approaches }\end{array}$ & Inter-ventions \\
\hline $\begin{array}{l}\text { Concepts and } \\
\text { Definition }\end{array}$ & 1.00 & & & & & \\
\hline $\begin{array}{l}\text { Incidence and } \\
\text { Prevalence }\end{array}$ & 0.35 & 1 & & & & \\
\hline $\begin{array}{l}\text { Causes and } \\
\text { Classification }\end{array}$ & 0.43 & 0.14 & 1 & & & \\
\hline $\begin{array}{l}\text { Clinical } \\
\text { Manifestation }\end{array}$ & 0.17 & 0.15 & 0.37 & 1 & & \\
\hline $\begin{array}{l}\text { Assessment } \\
\text { Approaches }\end{array}$ & 0.11 & 0.21 & 0.32 & 0.32 & 1 & \\
\hline Interventions & 0.10 & 0.42 & 0.33 & 0.15 & 0.20 & 1 \\
\hline
\end{tabular}

The correlation analysis provided in Table 6 shows that there is no issue of higher correlation in the variables used for the study and that all dimensions are not interdependent of each other. They also lack correlation between them as the value of each variable is less than 0.45 , which means that all variables are free from the issue of correlation. 
Moreover, it is observed that all dimensions of knowledge found are positively correlated.

Table 7. Regression Results

\begin{tabular}{llllll}
\hline Variables & Coefficients & t-statistics & Sig. & Tolerance & VIF \\
\hline Constant & 0.044 & 0.962 & 0.337 & & \\
Concepts and Definition & 0.210 & 19.928 & 0.000 & 0.959 & 1.042 \\
Incidence and Prevalence & 0.166 & 13.584 & 0.000 & 0.974 & 1.026 \\
Causes and Classification & 0.163 & 13.783 & 0.000 & 0.973 & 1.027 \\
Clinical Manifestations & 0.117 & 8.568 & 0.000 & 0.868 & 1.152 \\
Assessment Approaches & 0.187 & 14.328 & 0.000 & 0.870 & 1.149 \\
Interventions & 0.134 & 8.510 & 0.000 & 0.942 & 1.062 \\
\hline
\end{tabular}

$\mathrm{R}$ Square $=0.633$; Adjusted R Square $=0.630 ;$ Std. Error of the Estimate $=0.288 ; \mathrm{F}$ statistics $=257.08$; F statistics $($ sig. $)=$ 0.000 .

Linear regression is applied to measure the impact of different dimensions of knowledge on the overall knowledge level of primary school teachers regarding learning disabilities. For this, the study has taken the first six dimensions as independent variables and the level of knowledge as the dependent variable. Table 7 shows that all these six dimensions of knowledge are found to have a positive and statistically significant impact on the level of knowledge of school teachers in Saudi Arabia as their p-values are less than the level of significance of 0.05 . Fitness of regression line is measured by the value of $\mathrm{R}$ square. It measures the strength of association across the variables. The model has an $\mathrm{R}$ square value of 0.796 , which means that $79.6 \%$ variation in the level of knowledge is explained by the dimensions of knowledge. Standard deviation of error term is low indicating a good strength of regression estimation. The result of the regression model also reveals that the model is significant as its $F$ value is 0.000 , which is less than the level of significance of 0.05 .

\section{Findings}

Teachers play an important role in identifying children with learning difficulties. Indeed, they are the first to recognize childrens' difficulties in school. The objective of this study was to assess the knowledge of primary school teachers regarding children with learning disabilities. The study shows that there is a lack of such knowledge due to because they hadn't had awareness and special training courses. The distribution of primary school teachers according to their level of knowledge showed that a majority of them (64.52\%) had an average understanding of specific learning abilities and the remaining $35.48 \%$ had a poor level of knowledge regarding identification of learning disabilities. These findings are consistent with the earlier research by Shanker (2015), Karande, Bhosrekar, Kulkarni, and Thakker (2008), Shukla and Agarwal (2014) and Abhiyan (2005). Similar findings were also seen in a study conducted by Gerber (2005), where $86 \%$ of teachers identified that their knowledge regarding learning disabilities were low.

The present study shows that a majority of teachers had inadequate knowledge regarding the incidence and prevalence (0.93 mean value), causes and definition (1.11 mean value) and clinical manifestations (5.83 mean value). The primary teachers had adequate knowledge regarding approaches to assessment and outcomes for treating learning disabilities, with mean values of 3.83 and 1.23 respectively. These findings are supported by a study about awareness of learning disabilities, which explained that $32 \%$ were aware of the concept, $35 \%$ of the types of learning disabilities and $29 \%$ of the causes of learning disabilities (Shukla, 2015). These findings are also in agreement with the results of Shari and Vranda (2015) and Kakabarae, Arjmandnia and Afrooz (2012) that revealed $82.1 \%$ of teachers achieved a score higher than 10 for causes of learning disabilities. However, the findings were inconsistent with the research of Natekar (2012) which revealed that school teachers have a sound knowledge about the nature of learning disability.

The second objective was to address the relationship between the knowledge dimension and overall primary school teacher level of knowledge in Saudi Arabia. Regression results show that all 6 dimensions of knowledge were found to have a positive and statistically significant impact on their level of knowledge as the p-value for all variables is less than the level of significance of 0.05 . The model has an $\mathrm{R}$ square value of 0.796 indicating that $79.6 \%$ variation in the level of knowledge is explained by the dimensions of knowledge. The result of the 
regression model also reveals that the model is significant, as its $\mathrm{F}$ value is 0.000 which is less than the level of significance of 0.05 .

The third objective was to associate the knowledge scores with selected socio-demographic variables. There was a significant association of primary school teacher knowledge with socio-demographic variables such as gender, marital status, type of school and the class being taught. Another important finding was that there was no association between level of knowledge, teacher age and teaching experience. It is consistent with the studies conducted by Gandhimathi and Eljo (2010) and Lingeswaran (2013). The findings of the study on identification of learning disabilities explained that $85.9 \%$ of teachers hadn't attended any special courses on learning disabilities. $59.3 \%$ of them had never seen a child with a learning disability before, and only $40.7 \%$ of teachers were able to identify learning disabilities in their students. The study also found that there was a statistically significant difference in knowledge levels between male and female participants and between government and public school teachers.

\section{Conclusion}

Primary school teachers are deficient in knowledge and skill in spite of working with children with learning disabilities. Teachers do not have adequate knowledge regarding learning problems, and don't know what should be done when facing those problems. The present study assessed the knowledge of primary school teachers regarding learning disabilities among school children. The study concluded that the majority of the teacher's had average knowledge regarding learning disabilities. The results showed that all 6 dimensions of knowledge were found to have positive and statistically significant impact on the level of knowledge of school teachers. Moreover, level of knowledge had statistically significant relation to the teacher's gender, marital status, school type, level of class taught, and education. A learning package is an effective method to increase the competency of primary teachers regarding learning disabilities. The results evidenced that their knowledge about learning disabilities was superficial, because they did not have any courses about learning disabilities during their academic session. The institutes or government should arrange appropriate trainings or structured teachers program covering aspects of these dimensions about concepts, diagnosing and identifying special students with learning problems.

\subsection{Implications}

The government should launch awareness programs at the national level in order to encourage positive attitudes towards children with learning disabilities. The awareness programs should be developed to provide information about disabilities, their causes and the implications for improvement of life quality. On the other hand, the institutes should arrange appropriate training or structured teachers' programs covering aspects of concepts relating to learning disabilities and also the diagnosis and identification of those students with learning problems.

\subsection{Areas of Further Research}

Future researchers should consider additional variables such as the the quality and character of school life (the norms, beliefs and relationships of students, parents and the school personnel); the teaching and learning practices and structural features of the school (instructional technologies, class size and curriculum) to check their impact on the knowledge of primary school teachers regarding specific learning disabilities in children. In this regard, longitudinal studies should be used to examine teachers' attitudes before and after participating in long-term training courses. This will help in strengthening the knowledge of teachers about learning disabilities in Saudi Arabia.

Additionally, it would also be useful to investigate aspects of family support among children with learning disabilities.

\subsection{Research Limitations}

There are limitations regarding the random data sampling, timing and geographical constraints which might cause problems in generalization of our findings.

As data was taken in a single point in time, limited conclusions might only be able to be drawn from the observed sample, given that no longitudinal research is involved.

\section{Acknowledgements}

This project was funded by the Deanship of Scientific Research (DSR), at King Abdulaziz University, Jeddah, under grant no. (G- 423/279/39). The authors, therefore, acknowledge the DSR with thanks for their technical and financial support. 


\section{References}

Abed, M. G., \& Alrawajfh, S. (2017). Elementary school teachers' attitude towards including students with special educational needs into regular public schools in Saudi Arabia. International Journal of Education, 9(1), 49-66. https://doi.org/10.5296/ije.v9i1.10915

Adebowale, O. F., \& Moye, G. P. (2013). Teachers' knowledge of, and attitude towards learning disabilities. Online Educational Journal. Retrieved from www.orej.com.

Akpan, M. U., Ojinnaka, N. C., \& Ekanem, E. E. (2010). Academic performance of school children with behavioural disorders in Uyo, Nigeria. African Health Sciences, 10(2).

Al-Khatib, J. M. (2007). A survey of general education teachers' knowledge of learning disabilities in Jordan. International Journal of Special Education, 22(1), 72-76.

Al-Zoubi, S. M., \& Rahman, M. S. B. A. (2016). Mainstreaming in Kingdom of Saudi Arabia: Obstacles facing learning disabilities resource room. Journal of Studies in Education, 6(1), 37-55. https://doi.org/10.5296/jse.v6i1.8800

Alnaim, F. (2015). Learning disabilities concept and identification: Primary teachers' perspectives in Saudi Arabia. International Journal of Social Science and Humanity, 5(12), 1040. https://doi.org/10.7763/ijssh.2015.v5.601

Arab News (n.d.). Learning disabilities: $A$ reality in the Kingdom. Retrieved from https://learningdifferencesinesl.com/resources/lds-in-other-cultures/

Avramidis, E., \& Norwich, B. (2002). Teachers' attitudes towards integration/inclusion: A review of the literature. European Journal of Special Needs Education, 17(2), 129-147. https://doi.org/10.1080/08856250210129056

Bending, A. W. (1954). Reliability and the number of rating scale categories. Journal of Applied Psychology, 38, 38-40. http://dx.doi.org/10.1037/h0055647

Bhanwara, M. P., Kelkar, M. K., \& Mandalia, M. A. H. (2012). Knowledge among teachers related to behavioural problems in school children, Sinhgad College of Nursing.

Chappell, A. L., Goodley, D., \& Lawthom, R. (2001). Making connections: the relevance of the social model of disability for people with learning difficulties. British Journal of Learning Disabilities, 29(2), 45-50. https://doi.org/10.1046/j.1468-3156.2001.00084.x

Dalwai, A., Ahmad, S., \& Al-Nakib, W. (2010). Echoviruses are a major cause of aseptic meningitis in infants and young children in Kuwait. Virology journal, 7(1), 236. https://doi.org/10.1186/1743-422X-7-236

Das, J. P., Hayward, D., Samantaray, S., \& Panda, J. J. (2006). Cognitive Enhancement Training (COGENTC): What is it? How does it work with a group of disadvantaged children? Journal of Cognitive Education and Psychology, 5(3), 328-335. https://doi.org/10.1891/194589506787382440

Dharmaraj, P. (2000). Awareness of primary school teachers towards learning disabilities in mathematics at primary level. Unpublished M. Phil. Dissertation, Alagappa University.

Gandhimathi, U., \& Eljo, J. O. (2010). Awareness about learning disabilities among the primary school teachers. Cauvery Research Journal, 3(1), 71-78. https://doi.org/10.1111/j.1467-8624.2007.01069.x

George, D., \& Mallery, P. (2003). SPSS for Windows step by step: A simple guide and reference. Boston: Allyn and Bacon Publishers.

Gerber, M. M. (2005). Teachers are still the test: limitations of response to instruction strategies for identifying children with learning disabilities. Journal of Learning Disabilities, 38, 516-24. https://doi.org/10.1177/00222194050380060701

Ghimire, S. (2017). Knowledge of primary school teacher regarding learning disabilities in school children. Journal of Nobel Medical College, 6(1), 29-35. https://doi.org/10.3126/jonmc.v6i1.18084

Kakabaraee, K., Arjmandnia, A. A., \& Afrooz, G. A. (2012). The study of awareness and capability of primary school teachers in identifying students with learning disability in the province of Kermanshah. Procedia-Social and Behavioral Sciences, 46, 2615-2619. https://doi.org/10.1016/j.sbspro.2012.05.534

Kamala, R., \& Ramganesh, E. (2013). Knowledge of specific learning disabilities among teacher educators in Puducherry, Union Territory in India. International Review of Social Sciences and Humanities, 6(1), 168-175. 
Karande, S., Bhosrekar, K., Kulkarni, M., \& Thakker, A. (2008). Health-related quality of life of children with newly diagnosed specific learning disability. Journal of Tropical Pediatrics, 55(3), 160-169. https://doi.org/10.1093/tropej/fmn099

Karande, S., \& Gogtay, N. J. (2010). Specific learning disability and the right to education 2009 Act: Call for action. Journal of Postgraduate Medicine, 56(3), 171. https://doi.org/10.4103/0022-3859.68627

Karande, S., Sholapurwala, R., \& Kulkarni, M. (2011). Managing specific learning disability in schools in India. Indian Pediatrics, 48(7), 515-520. https://doi.org/10.1007/s13312-011-0090-1

Kline, P. (1986). A handbook of test construction: Introduction to psychometric design. New York: Methune.

Komorita, S. S. (1963). Attitude content, intensity, and the neutral point on a Likert scale. The Journal of Social Psychology, 61(2), 327-334. http://dx.doi.org/10.1080/00224545.1963.9919489

Komorita, S. S., \& Graham, W. K. (1965). Number of scale points and the reliability of scales. Educational and Psychological Measurement, 25(4), 987-995. http://dx.doi.org/10.1177/001316446502500404

Lingeswaran, A. (2013). Assessing knowledge of primary school teachers on specific learning disabilities in two schools in India. Journal of Education and Health Promotion, 2. https://doi.org/10.4103/2277-9531.115807

McDermott, R. (2001). The acquisition of a child by a learning disability. In J. Collins and D. Cook (Eds.), Understanding Learning: Influences and Outcomes (pp. 60-70). London: Paul Chapman Press. https://doi.org/10.1017/cbo9780511625510.011

Ministry of Education. (2012). Report of the Ministry of Education, New Zealand. Retrieved October 15, 2018.

Ministry of Health: Health statistical year book (2012). Riyadh: Ministry of Health. Retrieved from https://www.moh.gov.sa/en/Ministry/Statistics/Pages/default.aspx

Moothedath, S., \& Vranda, M. N. (2015). Knowledge of primary school teachers in identifying children with learning disabilities. Disability, CBR \& Inclusive Development, 26(3), 68-76. https://doi.org/10.5463/DCID.v26i3.443

Myers, S. M., \& Johnson, C. P. (2007). Management of children with autism spectrum disorders. Pediatrics, 120(5), 1162-1182. https://doi.org/10.1542/peds.2007-2362

National Institute of Neurological Disorders and Stroke. (n.d.). Dyslexia information page. Retrieved March 6, 2017, from https://www.ninds.nih.gov/Disorders/All-Disorders/Dyslexia-Information-Page\#disorders-r1

Gururaj, G., Kolluri, S. V. R., Chandramouli, B. A., Subbakrishna, D. K., \& Kraus, J. F. (2005). Traumatic brain injury. National Institute of Mental Health \& Neuro Sciences, Publication no. 61, Bangalore - 560029.

Padhy, S. K., Goel, S., Das, S. S., Sarkar, S., Sharma, V., \& Panigrahi, M. (2016). Prevalence and patterns of learning disabilities in school children. The Indian Journal of Pediatrics, 83(4), 300-306. https://doi.org/10.1007/s12098-015-1862-8.

Padmavathi, D., \& Lalitha, K. (2009). Effectiveness of structured teaching programme for teacher trainees towards learning disabilities. Nightingale Nursing Times, 5(4), 14-23.

Priestley, M. (2003). Disability: A life course approach. Cambridge: Polity Press.

Raju, S. (2015). A study to assess the effectiveness of structured teaching programme on knowledge regarding learning disability among school teachers at selected schools, Kerala. A dissertation submitted to the Tamil Nadu Dr. M. G. R. Medical University, Chennai in partial fulfillment of requirement for the Degree of Master of Science in Nursing.

Rowan, C. (2014). 10 reasons why handheld devices should be banned for children under the age of 12. Huffington Post, 9.

Sakhuja, S. (2004). Education for all and learning disabilities in India. Retrieved September 25, 2011, from www.sspconline.org/opinion/EducationforAllandLearningDisabilitiesinIndia_SangeetaSakhuja_041004

Shanker, D. (2015). Education and academic entrepreneurship in India. IIM Bangalore Research Paper No. 494. https://doi.org/10.2139/ssrn.2625903

Shari, M., \& Vranda, M. N. (2016). Attitude of primary school teachers towards children with learning disabilities Journal of Indian Association of Child Adolescent Mental Health 12 (4): 323-335. https://eds-b-ebscohostcom.ezp.waldenulibrary.org/eds/pdfviewer/pdfviewer?vid=1\&sid=1f19f964e89c-4e18-b05e-6ad3bb05a7f2\%40sessionmgr120 
Shari, M., \& Vranda, M. N. (2015). Knowledge of primary school teachers in identifying children with learning disabilities, Disability, CBR and Inclusive Development, 26(3) 68-76. https://doi.org/10.5463/DCID.v26i3.443

Shenoy, J., \& Kapur, M. (1996). Prevalence of scholastic backwardness among five to eight year old children. Indian Journal of Psychiatry, 38(4), 201.

Shukla, P., \& Agrawal G. (2015). Awareness of learning disabilities among teachers of primary schools. Open Journal of Medical Research, 1, 33-38. Retrieved from https://www.researchgate.net/publication/283574444

Singal, N. (2005). Responding to difference: Policies to support "inclusive education" in India. Inclusive and Supportive Education Congress (pp. 1-4). University of Strathclyde, Glasgow. Retrieved from http://www.isec2005.org.uk/isec/abstracts/papers_s/singal_n.shtml.

Vandenberg, B., \& Emery, D. (2009). A longitudinal examination of the remediation of learning disabilities: IQ, age at diagnosis, school SES and voluntary transfer. International Journal of Special Education, 24(1), $45-52$.

Wheldall, K., \& Limbrick, L. (2010). Do more boys than girls have reading problems? Journal of Learning Disabilities, 43(5), 418-429. https://doi.org/10.12691/education-1-1-5

World Health Organization (WHO). (2003). Child mental and psychological development. WHO Technical Report Series, 613(1), 14-31. Retrieved from www.who.int/worldhealthreport/2003.pdf

Williams, A., Singh, G., \& Narayan, P. (2013). Competency of School Teachers Regarding Learning Disabilities. IOSR Journal of Nursing and Health Science, 2(2), 20-23.

\section{Copyrights}

Copyright for this article is retained by the author(s), with first publication rights granted to the journal.

This is an open-access article distributed under the terms and conditions of the Creative Commons Attribution license (http://creativecommons.org/licenses/by/4.0/). 